\title{
Cancer cell sensitivity to bortezomib is associated with survivin expression and p53 status but not cancer cell types
}

\author{
Xiang Ling ${ }^{1}$, Diane Calinski ${ }^{1}$, Asher A Chanan-Khan ${ }^{2,3}$, Muxiang Zhou ${ }^{4}$, Fengzhi Li, ${ }^{1,3^{*}}$
}

\begin{abstract}
Background: Survivin is known playing a role in drug resistance. However, its role in bortezomib-mediated inhibition of growth and induction of apoptosis is unclear. There are conflicting reports for the effect of bortezomib on survivin expression, which lacks of a plausible explanation. Methods: In this study, we tested cancer cells with both p53 wild type and mutant/null background for the relationship of bortezomib resistance with survivin expression and p53 status using MTT assay, flow cytometry, DNA fragmentation, caspase activation, western blots and RNAi technology.

Results: We found that cancer cells with wild type p53 show a low level expression of survivin and are sensitive to treatment with bortezomib, while cancer cells with a mutant or null p53 show a high level expression of survivin and are resistant to bortezomib-mediated apoptosis induction. However, silencing of survivin expression utilizing survivin mRNA-specific siRNA/shRNA in p53 mutant or null cells sensitized cancer cells to bortezomib mediated apoptosis induction, suggesting a role for survivin in bortezomib resistance. We further noted that modulation of survivin expression by bortezomib is dependent on p53 status but independent of cancer cell types. In cancer cells with mutated p53 or p53 null, bortezomib appears to induce survivin expression, while in cancer cells with wild type p53, bortezomib downregulates or shows no significant effect on survivin expression, which is dependent on the drug concentration, cell line and exposure time.

Conclusions: Our findings, for the first time, unify the current inconsistent findings for bortezomib treatment and survivin expression, and linked the effect of bortezomib on survivin expression, apoptosis induction and bortezomib resistance in the relationship with p53 status, which is independent of cancer cell types. Further mechanistic studies along with this line may impact the optimal clinical application of bortezomib in solid cancer therapeutics.
\end{abstract}

\section{Background}

Although bortezomib (PS-341) was largely applied to treatment of hematopoietic malignancy such as myeloma, growing basic studies and clinical trials reveal that bortezomib can be used to treat many types of solid tumors alone and in combination with other chemotherapeutic drugs. This includes colon-gastric cancer [1-3], breast cancer [4-9], prostate cancer [10-14] and lung cancer [15-18] as well as others. Therefore, use of solid tumor-derived cancer cell lines to study the mechanism of bortezomib drug resistance is important for effective

\footnotetext{
* Correspondence: fengzhi.li@roswellpark.org

'Departments of Pharmacology \& Therapeutics, Roswell Park Cancer Institute, Buffalo, New York 14263, USA
}

application of bortezomib in treatment of patients with solid tumors in the clinic.

Survivin, a unique member of the Inhibitor of Apoptosis (IAP) Protein Family, is cell cycle-regulated $[19,20]$ and its expression in cancer has been associated with cancer progression, drug resistance, and shortened patient survival $[21,22]$. Given that survivin is highly expressed in malignant cells but is undetectable in most normal adult tissues, it is considered as a potentially important therapeutic target [23]. Survivin antagonizes apoptosis and is involved in the mitotic spindle assembly checkpoint $[24,25]$. Thus, inhibition of survivin expression or function induces both apoptosis and cell division defect. Many protein factors and

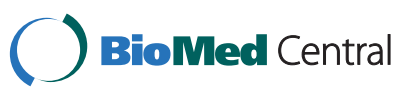


signaling transduction pathways can modulate the expression of survivin [26]. For example, it has been reported that p53 transcriptionally downregulates the expression of survivin in various cancer cells with wild type p53 [27-29], and the inhibition of survivin by p53 can be reversed by growth-stimulatory factors such as estrogen receptor- $\alpha$ [30].

While survivin is a known universal drug resistant factor, the role and expression for survivin in bortezomibinduced cancer cell growth inhibition and apoptosis induction remains unclear. Some of the previous reports noted that treatment of cancer cells with bortezomib is associated with enhanced apoptosis and reduced expression of survivin [31,32], while other investigators reported that bortezomib-induced apoptosis is accompanied with an induction of survivin expression in human NSCLC cells [33]. Recently, it has been also reported that the role for survivin in bortezomib-induced apoptosis is cell type-dependent [34]. In this study, we demonstrated that modulation of survivin expression by bortezomib is dependent on p53 status but independent of cancer cell type. In cancer cells with mutated p53 or p53 null, bortezomib appears to induce survivin expression, while in cancer cells with wild type p53, bortezomib either downregulates or shows no significant effect on survivin, which is dependent on cell line, bortezomib concentration and duration of exposure. These findings, for the first time, unified the current different observations about the effect of bortezomib on survivin expression, apoptosis induction and bortezomib resistance, and warranted further mechanistic studies and application of these findings in cancer therapeutics.

\section{Methods}

\section{Cell culture and reagents}

Colon cancer cell lines (HCT116p53 ${ }^{+/+}, \mathrm{HCT} 116 \mathrm{p} 53^{-/-}$), lung cancer cell lines (EKVX and A549), prostate cancer cells (PC-3 and LNCaP) and multiple myeloma cell lines (KMS11 and RPMI8226) were maintained in RPMI 1640 medium. Breast cancer cells (MDA-MB-231 and MCF7) were cultured in DMEM medium. All cell cultural mediums were supplied with $10 \%$ fetal bovine serum (FBS, Atlanta Biologicals, Lawrenceville, GA) and penicillin $(100 \mathrm{units} / \mathrm{ml}) /$ streptomycin $(0.1 \mu \mathrm{g} / \mathrm{ml})$ (Invitrogen, Grand Island, NY). Cells were routinely subcultured twice a week and maintained in a humidified incubator with $5 \% \mathrm{CO} 2$ at $37^{\circ} \mathrm{C}$. Polyclonal antiactin antibody and goat peroxidase-conjugated anti-rabbit IgG antibody were purchased from Sigma (St. Louis, MO). Survivin antibody (FL-142) was purchased from Santa Cruz (Santa Cruz, CA), MTT (tetrazolium salt, 3[4,5-dimethylthiazol-2-yl]-2,5,-diphenyltetrazolium bromide) and leupeptin were purchased from Usb (Cleveland, $\mathrm{OH}$ ).

\section{Cell treatment and siRNA/shRNA transfection/infection}

Cells grown in medium containing $10 \%$ serum were treated with and without bortezomib in various concentrations (see text and results) for 24 - 72 hours were harvested and followed by various analyses. siRNA transfection [35] and shRNA infection [36] were performed as previously described

\section{MTT cell viability assay}

Effect of bortezomib on cell growth was determined by MTT assay. MTT was used as a colorimetric substrate for measuring cell viability. Non-viable cells, with altered cellular redox activity, are unable to reduce the MTT dye. After 72 hours with or without bortezomib treatment, MTT was added (to a final concentration of 0.5 $\mathrm{mg} / \mathrm{ml}$ ). Cells in 96-well plates were incubated in a $5 \%$ $\mathrm{CO}_{2}$ incubator at $37^{\circ} \mathrm{C}$ for 4 hours, and then lysed thoroughly with lysis buffer (20\% SDS, $50 \% \mathrm{~N}$, N-dimethylformamide, $\mathrm{pH} 4.7,100 \mu \mathrm{l} /$ well). The absorbance in the relevant wells was measured at $570 \mathrm{~nm}$ using an Ultra Microplate Reader (Bio-Tek Instruments).

\section{Flow cytometry analysis}

Cells at sub-confluence $(\sim 30 \%)$ were treated with bortezomib at 0, 5, 10 and $50 \mathrm{nM}$ for 48 hours and then harvested by trypsinization and washed with PBS. Cells $(\sim 1$ $\times 10^{6}$ ) were resuspended in $5 \mathrm{ml} 70 \%$ ethanol. After the initial fixation, cells were suspended in $0.5 \mathrm{ml}$ PBS containing $25 \mu \mathrm{g} / \mathrm{ml}$ propidium iodide (PI), $0.2 \%$ Triton X100 and $40 \mu \mathrm{g} / \mathrm{ml}$ RNase A and incubated for at least 30 minutes at $4^{\circ} \mathrm{C}$. Cells were then analyzed for DNA content profile by flow cytometry (FACScan, Becton Dickinson, San Jose, CA) from 10,000 events per sample. Data from flow cytometry were analyzed using WinList software (Verity Software House Inc., Topsham, ME) and presented as DNA content profiles (X axle) over cell numbers (y axle). Triplicate assays were performed.

\section{Western blot analysis}

Cells with and without bortezomib treatment were washed with phosphate-buffered saline (PBS) and lysed on ice for 30 minutes in PBS containing $1 \%$ Nonidet P$40,0.5 \%$ sodium deoxycholate, $0.1 \%$ sodium dodecyl sulfate (SDS), $10 \mu \mathrm{g} / \mathrm{ml}$ phenylmethyl sulfonyl fluoride, and $20 \mu \mathrm{M}$ leupeptin. Cell lysates were then centrifuged at $15,000 \mathrm{~g}$ for 20 minutes at $4^{\circ} \mathrm{C}$. Fifty $\mu \mathrm{g}$ total proteins from each sample were heated at $95^{\circ} \mathrm{C}$ for 5 minutes after mixing with equal volume of $2 \times$ SDS loading buffer. Samples were separated on 12 - 15\% SDS-polyacrylamide gel electrophoresis (SDS-PAGE) gels and electrotransferred to Pure Nitrocellulose Membranes (Bio-Rad, Hercules, CA). The membrane was then blocked in $5 \%$ skim milk in TBS-T buffer (20 mM Tris/ $\mathrm{HCl}(\mathrm{pH} 7.5), 0.137 \mathrm{M} \mathrm{NaCl}$, and $0.05 \%$ Tween 20) at room temperature for 2-3 hours; followed by incubation of the membrane with primary antibodies (against survivin or actin) in TBS-T containing 5\% BSA overnight at 
$4^{\circ} \mathrm{C}$ in the range of dilutions from 1:1000 to $1: 4000$. After washing with TBS- $T$, the membrane was incubated in TBS-T buffer containing 5\% skim milk containing the corresponding secondary antibody (1:5000) for 45-60 minutes at room temperature with shaking. Protein of interest was detected using ECL (Perkin Elmer, Waltham, MA) and visualized by autoradiography with various times (5-60 seconds) of exposure. Actin was detected as the internal control for normalization of total protein loading in each lane.

\section{Cell death detection ELISA assay}

This assay is based on cell DNA fragmentation and the cell death/DNA fragmentation was detected using the Cell Death Detection ELISA ${ }^{\text {Plus }}$ assay kit (Roche) as described previously [37]. Briefly, transfected HCT116p53-/- cells were seeded in triplicates in 96-well plates and treated with and without bortezomib for 48 hours. After removing medium, cells were then lysed and $20 \mu \mathrm{l}$ of lysate supernatant from each well were dispensed into streptavidin-coated well-removable 96-well plates followed by addition of $80 \mu \mathrm{l}$ of immuno-reagents. After a 2-hour incubation at room temperature, unbound components were removed by washing with $1 \times$ incubation buffer for 3 times, followed by adding 100 $\mu \mathrm{l}$ of HRP substrate to each well, and the plate was placed on a shaker at $250 \mathrm{rpm}$ for color development. Measurements were made at $405 \mathrm{~nm}$ against an ABTS solution as a blank control using a microplate reader. The absorbance value at $405 \mathrm{~nm}$ represents the quantities of DNA fragments/apoptosis induced by the treatment.

\section{Statistical analysis}

A t-test was performed for a pair-wise comparison of each experimental pair group with the control assuming equal variance. The significance ( $\mathrm{p}$-value marked with an asterisk “*”) was set at equal to or less than 0.05 .

\section{Results}

\section{Bortezomib-induced growth inhibition in HCT116 colon} cancer cells is dependent on p53 statuses

It was found that wild type p53 transcriptionally inhibits survivin expression [27-29]. We reasoned that if survivin plays a role in bortezomib resistance, p53 status might affect bortezomib sensitivity to inhibit cancer cell growth. Consistent with our rationale, p53 null HCT116 cells (HCT116p53/-) were resistant to bortezomibinduced cell growth inhibition in comparison with HCT116 with wild type p53 (Fig 1). This suggests a role for the p53 status in bortezomib-induced cancer cell growth inhibition, however it is not known whether the difference of p53 status can also affect bortezomibinduced cell death.

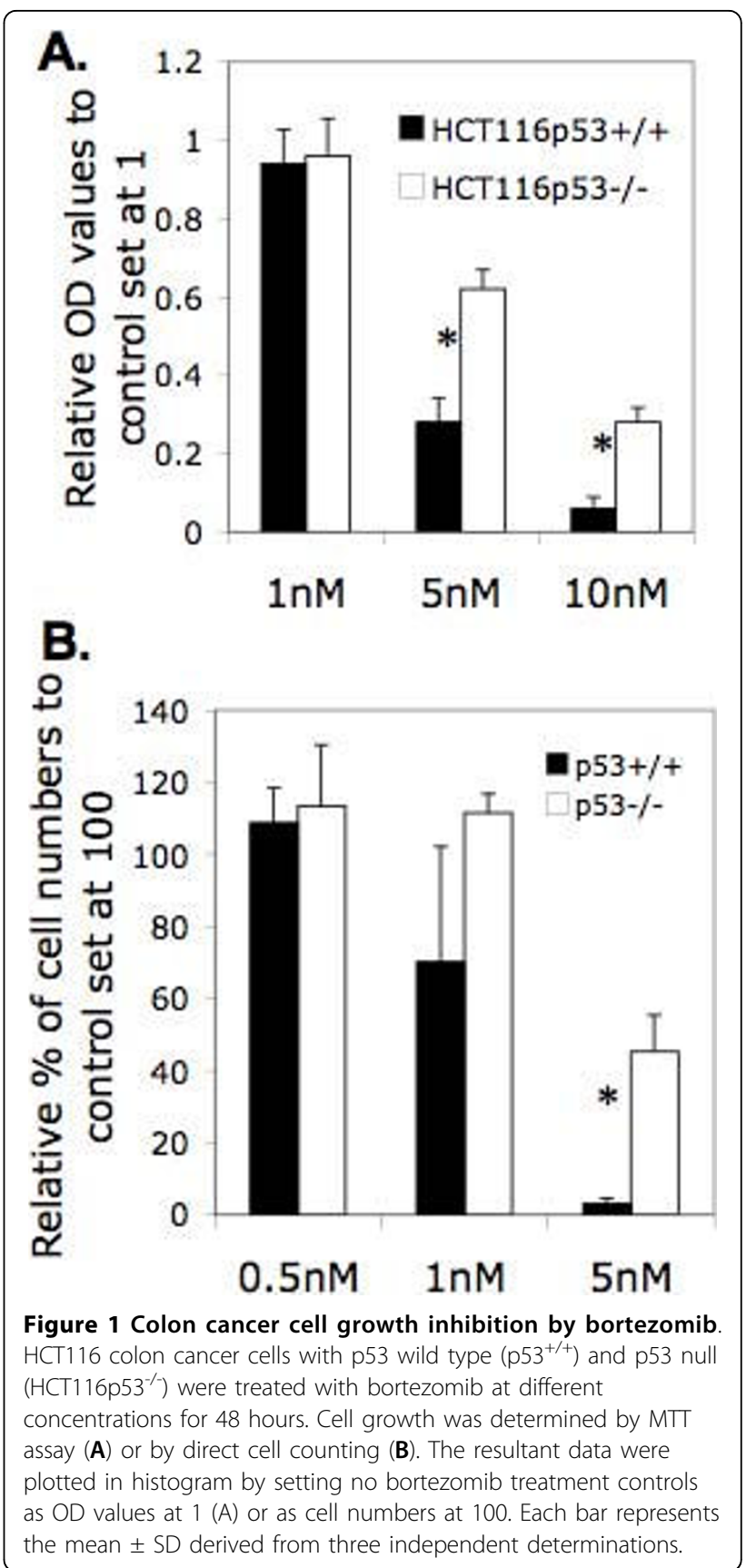

HCT $116 \mathrm{p} 53^{-/-}$colon cancer cells are much more resistant to bortezomib-mediated cell death in comparison with wild type HCT116 cells

We then tested the effect of bortezomib on the induction of HCT116 colon cancer cell death with different p53 status. Flow cytometry was used to determine DNA content profiles as a parameter to evaluate cell death after bortezomib treatment. This experiment revealed that bortezomib treatment for 24 hours at 10 and 50 nM significantly induced sub-G1 DNA (representing 
dead cells) content increase in HCT $116 \mathrm{p} 53^{+/+}$cells, while this treatment showed minimal effect on HCT $116 \mathrm{p} 53^{-/-}$cells (Fig. 2). These observations (Figs 1 and 2) prompted us to investigate the potential role for survivin in bortezomib resistance.

Survivin expression is much higher in HCT116p $53^{-/-}$cells than in $\mathrm{HCT} 116 \mathrm{p} 53^{+/+}$cells

We reasoned that if survivin plays a role in bortezomib resistance, survivin expression would be lower in HCT116p53 $3^{+/+}$cells than in HCT116p53-/- cells. Alternatively, bortezomib may decrease survivin expression in HCT $116 \mathrm{p} 53^{+/+}$cells or increase survivin expression in HCT116p53 $3^{-/-}$cells. To test the former possibility, survivin expression was determined by western blots in both HCT116p53 $3^{+/+}$cells and HCT116p53 $3^{-/}$cells. The result indicated that the expression of survivin in HCT116p53 ${ }^{+/+}$cells is much lower than in HCT116p53 $3^{-/-}$cells (Fig. $3 \mathrm{~A})$, suggesting the high expression of survivin in HCT116p $53^{-1-}$ cells may act as a contributing factor to bortezomib resistance. Similar results were obtained in other cancer cell lines with different p53 status (Fig. 3B). Consistently, MDA-MB-231 has much higher tumorigenic ability than MCF-7 in mouse xenograft models.

Bortezomib induces survivin expression in HCT116p $53^{-/-}$ cells but shows no significant effect on survivin expression in HCT116p53 $3^{+/+}$cells

We then tested whether bortezomib could differentially modulate survivin expression between HCT116p53+/+ cells and $\mathrm{HCT} 116 \mathrm{p} 53^{-/-}$cells. Consistent with the fact that HCT116p $53^{-/-}$cells are resistant to bortezomibinduced growth inhibition and apoptosis induction, bortezomib appears to significantly induce survivin expression in HCT $116 \mathrm{p} 53^{-/-}$cells, while it shows minimal induction of survivin in HCT116p53 ${ }^{+/+}$cells (Fig. 4A). Similar results were also obtained in other cancer cell lines (Fig. 4B), indicating a general principle of this phenomenon.

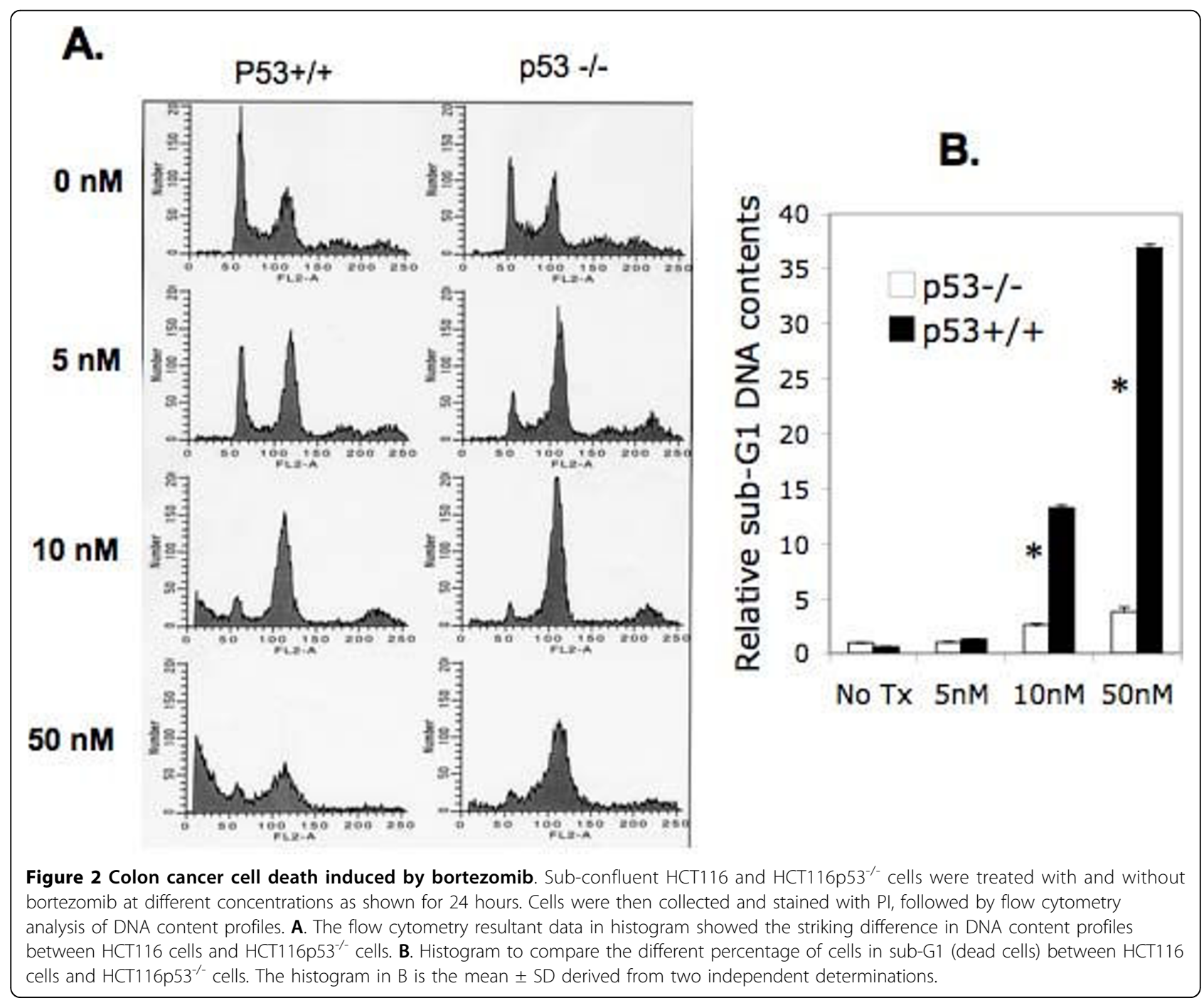




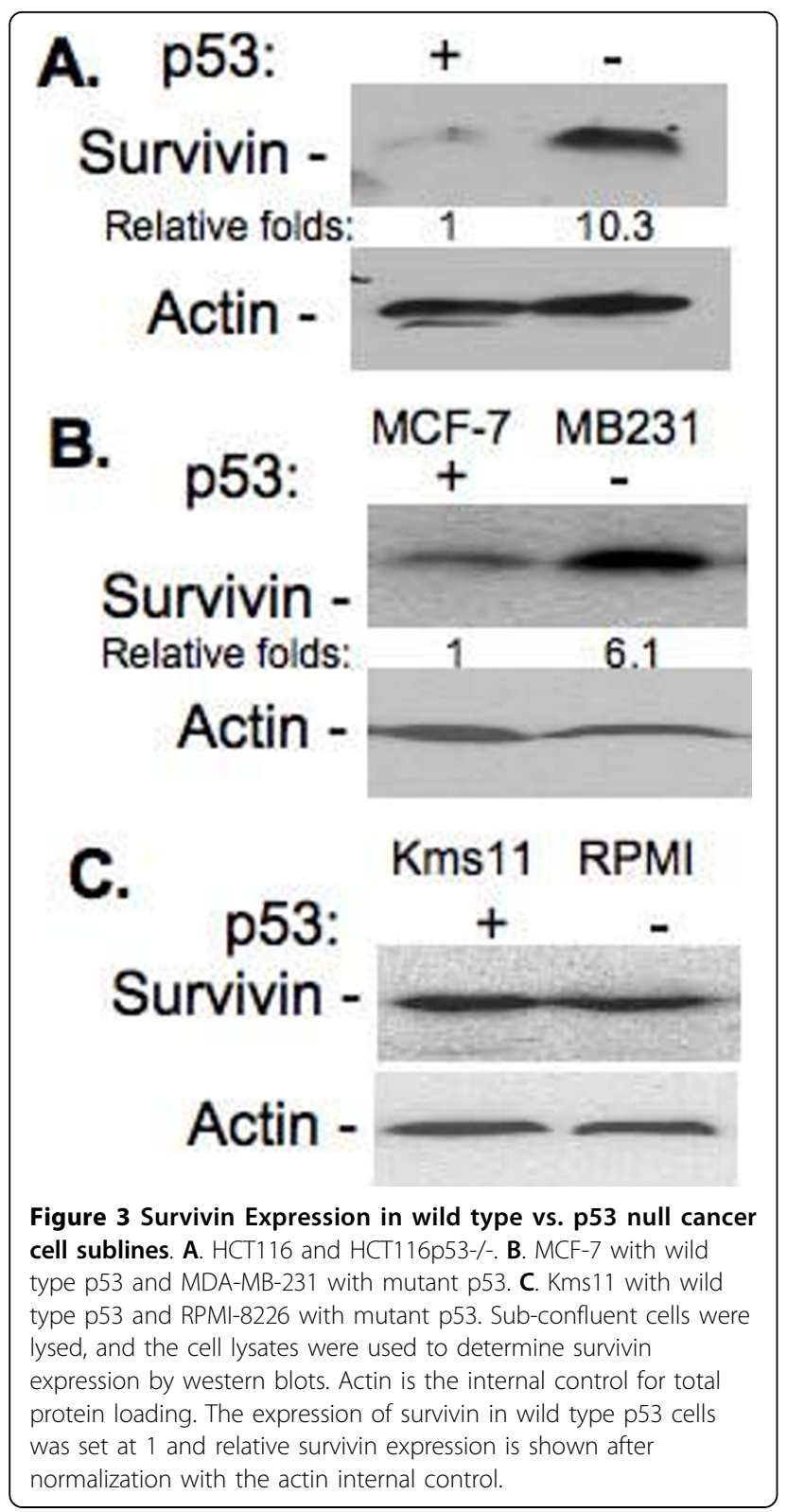

Silencing of survivin expression in HCT116p53-/- cells by survivin mRNA-specific siRNA sensitizes bortezomibinduced growth inhibition

To test whether survivin expression indeed plays a role in bortezomib resistance, we employed survivin mRNAspecific siRNA approach [35] to silence survivin expression in HCT116p53-/- cells, which highly expresses survivin. Significantly, we noted that silencing of the expression of survivin (Fig. 5A) reverses bortezomib resistance to growth inhibition (Fig. 5B) and cell death induction (Fig. 5C) in HCT116p53-/- cells, while control siRNA only showed a background effects similar to those without transfection (not shown). Similarly, silencing of survivin expression in MDA-MB-231 (p53 mut) and PC-3 (p53 null) cells activates caspase-3 (Fig. 6), a hallmark of apoptosis. These studies provide direct evidence for the involvement of survivin expression in bortezomib resistance.

Cancer cell sensitivity to bortezomib treatment is dependent on p53 status but not cancer cell types

Previous studies indicated that modulation of survivin expression by bortezomib, and cancer cell sensitivity to bortezomib-induced apoptosis are cell type-dependent [34]. Based on the data provided above, we hypothesized that the different sensitivity to bortezomib for cancer cells is due to p53 status-associated differential survivin expression, and induction by bortezomib, rather than cancer cell type. Here, we tested four pairs of cancer cell lines with different p53 status from lung cancer (EKVX with mutant p53 versus A549 with wild type p53), breast cancer (MDA-MB-231 with mutant p53 versus MCF-7 with wild type p53), prostate cancer (PC3 with null p53 versus $\mathrm{LNCaP}$ with wild type p53) and myeloma (RPMI-8226 with mutant p53 versus Kms11 with wild type p53). Consistent with our early data and our rationale, bortezomib-mediated inhibition of cell growth is significantly better in cancer cell lines with wild type p53 in comparison to those cell lines with a p53 null or p53 mutant status (Fig. 7), which is consistent with the relative expression level of survivin in these cells (Fig. 3A and 3B).

\section{Discussion}

Bortezomib is the first in class, proteasome inhibitor that has demonstrated significant anticancer activity in patients with lymphoid malignancies especially multiple myeloma [38,39]. However, growing studies indicated the potential effectiveness of bortezomib in treatment of patients with solid tumor including colon-gastric cancer [1-3], breast cancer [4-9], prostate cancer [10-14] and lung cancer [15-18]. However, despite its impressive single agent clinical activity in patients with either hematopoietic or solid malignancy, most patients either fail to respond or develop resistance to bortezomib treatment. Therefore, resistance to bortezomib is a challenging problem in the clinic. Identifying mechanism of bortezomib resistance not only can help identify novel therapeutic targets but will also contribute to better utilization of this important therapeutic agent.

In the present study, we focus on the role of survivin and p53 in bortezomib effectiveness as well as their functional relationship in solid tumor cell lines. We found that cancer cells with wild type p53 express much less survivin in comparison with cancer cells with either mutant or null p53. Moreover, bortezomib significantly increased survivin expression in the HCT116 colon or other cancer cell lines with p53 null, while it only showed a minimal effect on survivin expression in 


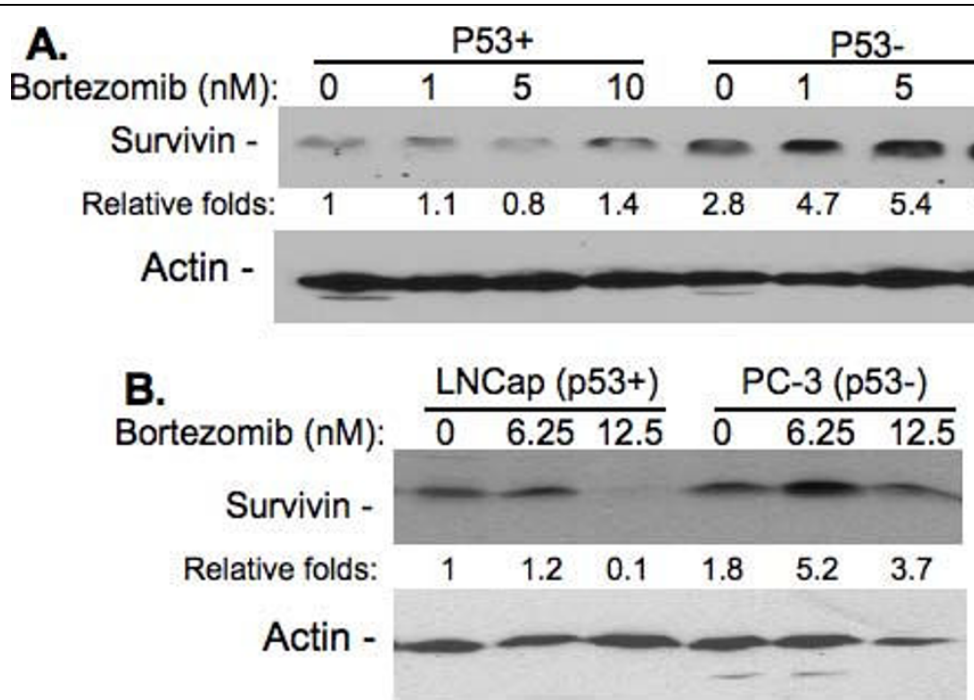

Figure 4 Differential effects of bortezomib on survivin in HCT116p53 $3^{-/-}$cells versus HCT116 cells. A. HCT116 and HCT116p53-/. B. LNCap with wild type p53 and PC-3 with null p53. Sub-confluent cells were treated with and without bortezomib for 48 hours. Cells were then collected and lysed for western blots to determine survivin expression. Actin was used as the internal control for total lysate protein loading. The expression of survivin in wild type p53 cells was set at 1 and relative survivin expression is shown after normalization with actin.
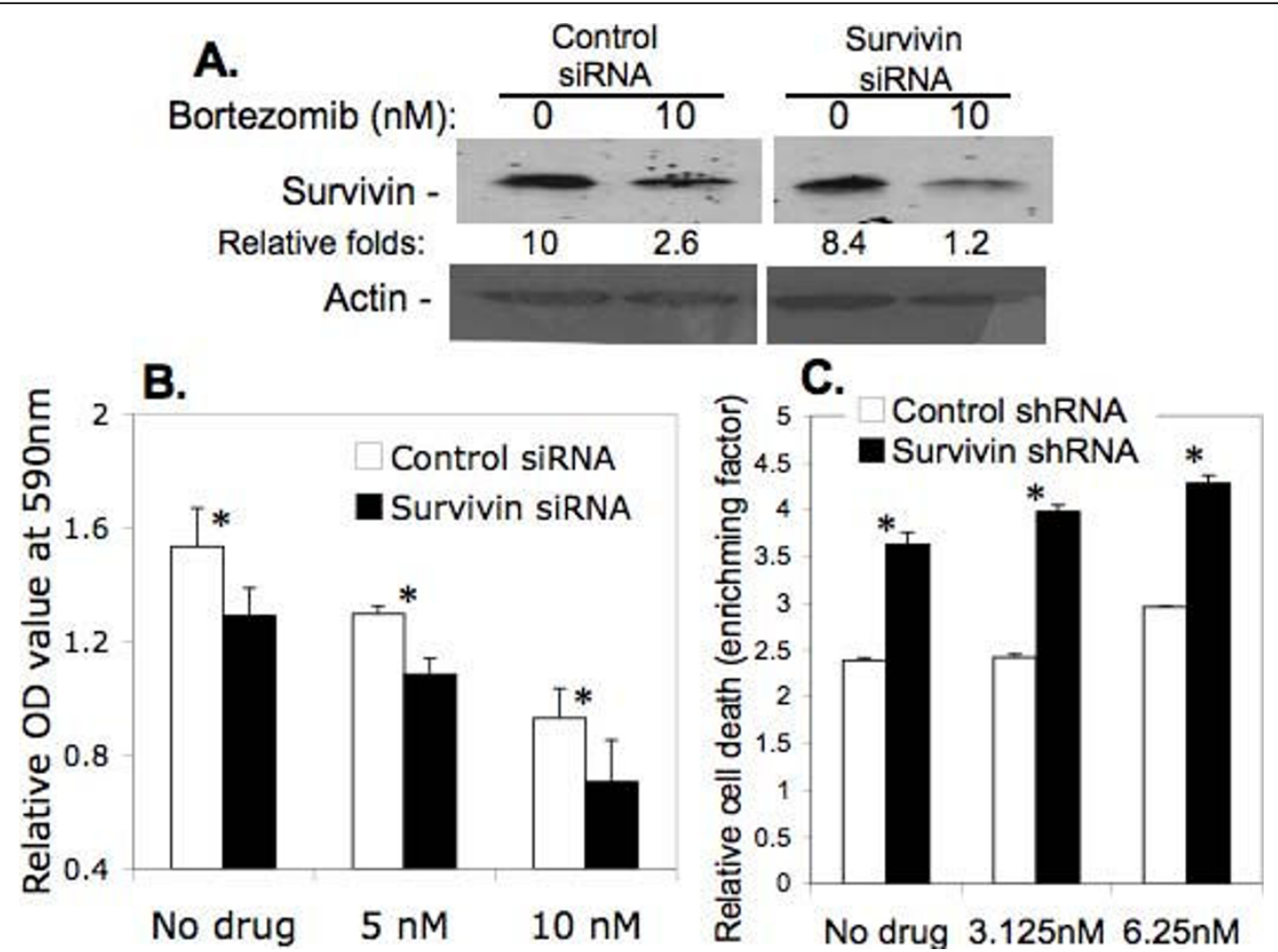

Figure 5 Effects of silencing of survivin expression on bortezomib sensitivity in HCT116p53-/- cells. The highly survivin expressing HCT116p53-/- cells at 50\% confluence were transfected with survivin mRNA-specific siRNAs or with control siRNAs. After 16 hours post transfection, cells were treated with and without bortezomib for 48 hours. A part of the transfected cells were then collected for western blots to determine survivin expression (A), a part of the transfected cells was used to determine cell growth inhibition by MTT assay (B), and the other part of the transfected cells was used to determine cell death/DNA fragmentation by cell death ELISA assay (C). Data shown in B and C are the mean \pm SD derived from three independent determinations. Note: Results from cells without transfection were similar to cells transfected with control siRNA/shRNA (not shown). The expression of survivin in HCT116p53-/- cells was set at 10 and relative survivin expression levels are shown after normalized to actin. 


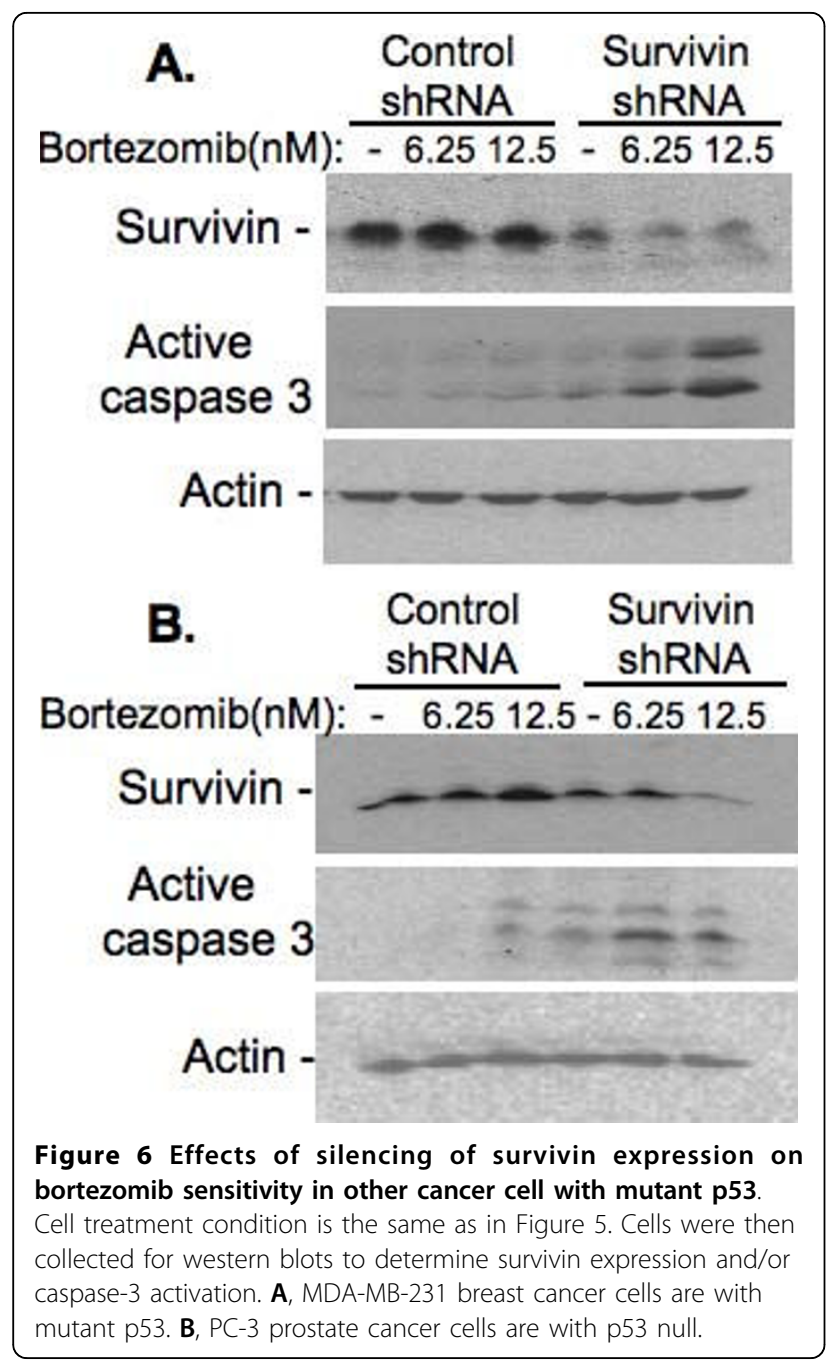

HCT116 and other cancer cells with wild type p53. Consistent with these findings, while bortezomib effectively inhibited cell growth and induced cell death in cancer cells with wild type p53, bortezomib showed ineffectiveness to inhibit cell growth and induce cell death for the cancer cells with abnormal p53 (null or mutated). We recognized that our experiment in Fig. 7 will be more convincing, if pairs of cancer cell lines as we have for the HCT116 line (HCT116p53 ${ }^{+/+}$vs. HCT116 $53^{-1-}$ ) could be available to us for these experiment. Nevertheless, the role of survivin in bortezomib resistance was directly demonstrated in the study by silencing of survivin in several cancer cell lines with mutant p53 using survivin mRNA-specific siRNA/ shRNA technology previously set up in our laboratory $[35,36]$. Finally, our investigations in three different pair of cancer cell lines (originating from breast, lung and prostate) with different p53 status demonstrated that the p53 status-associated survivin expression is an essential parameter to predict bortezomib resistance irrespective of the origin of the cancer cell. Cancer cells having a wild type p53 were sensitive while those with abnormal p53 (mutated or null) were resistant to bortezomib treatment. Consistent with these findings, previous studies found that wild type p53 transcriptionally inhibits survivin expression in various cancer cell types [27-29] and bortezomib can stabilize wild type p53 in prostate cancer cells [40]. Here, we would like to point out that the bortezomib concentration used affects the results, suggesting the dose used in the clinic should be carefully considered. When high dose may kill cancer cells better in a short term, high dose will increase the possibility to generate bortezomib resistance, suggesting that in addition to p53 status-associated survivin expression, other factors, such as other protein members in the IAP and Bcl-2 families may also play important roles in bortezomib resistance. Nevertheless, we have confirmed a role for survivin in bortezomib resistance by direct silencing of survivin expression using survivinspecific siRNA/shRNA. This finding is significant because our recent studies indicated that survivin may be a superior cancer stem cell marker and possibly plays critical role in cancer stem cell expansion [41]. In this regard, cancer cells appear to have a higher percentage of subpopulation cells that are tumorigenic (cancer initiating/cancer stem cells) in xenograft mouse models [42].

Therefore, consideration of both survivin expression and p53 status as interconnecting biomarkers and targets in cancer cells may not only be useful for predicting the outcome of bortezomib treatment, but may also provide pivotal criteria for rational drug combination. For example, bortezomib likely induces survivin expression in cancer cells with mutated or null p53 (this study), and it is known that paclitaxel rapidly induces survivin expression [43]. Thus, combination of bortezomib and paclitaxel likely obtained no good results in many cancer types with such as the mutated p53 background. Accordingly, a recent Phase II study in patients with metastatic esophageal, gastric, and gastroesophageal cancer showed poor results in the drug combination [44]. However, it is also possible that the poor results derived from such a drug combination involve other mechanisms of drug resistance in these tumors that are notoriously difficult to treat with chemotherapy.

An important question that needs be answered for better application of the findings is the mechanism underlying bortezomib-mediated induction of survivin expression in mutated or null p53 cancer cells, while it showed downregulation of or minimal effect on survivin expression in wild type p53 cancer cells. Although answering this critical question will need further research efforts, based on the current available information, the potential p53 and NF- $\kappa$ B functional crosstalk could provide a plausible explanation, although need to 


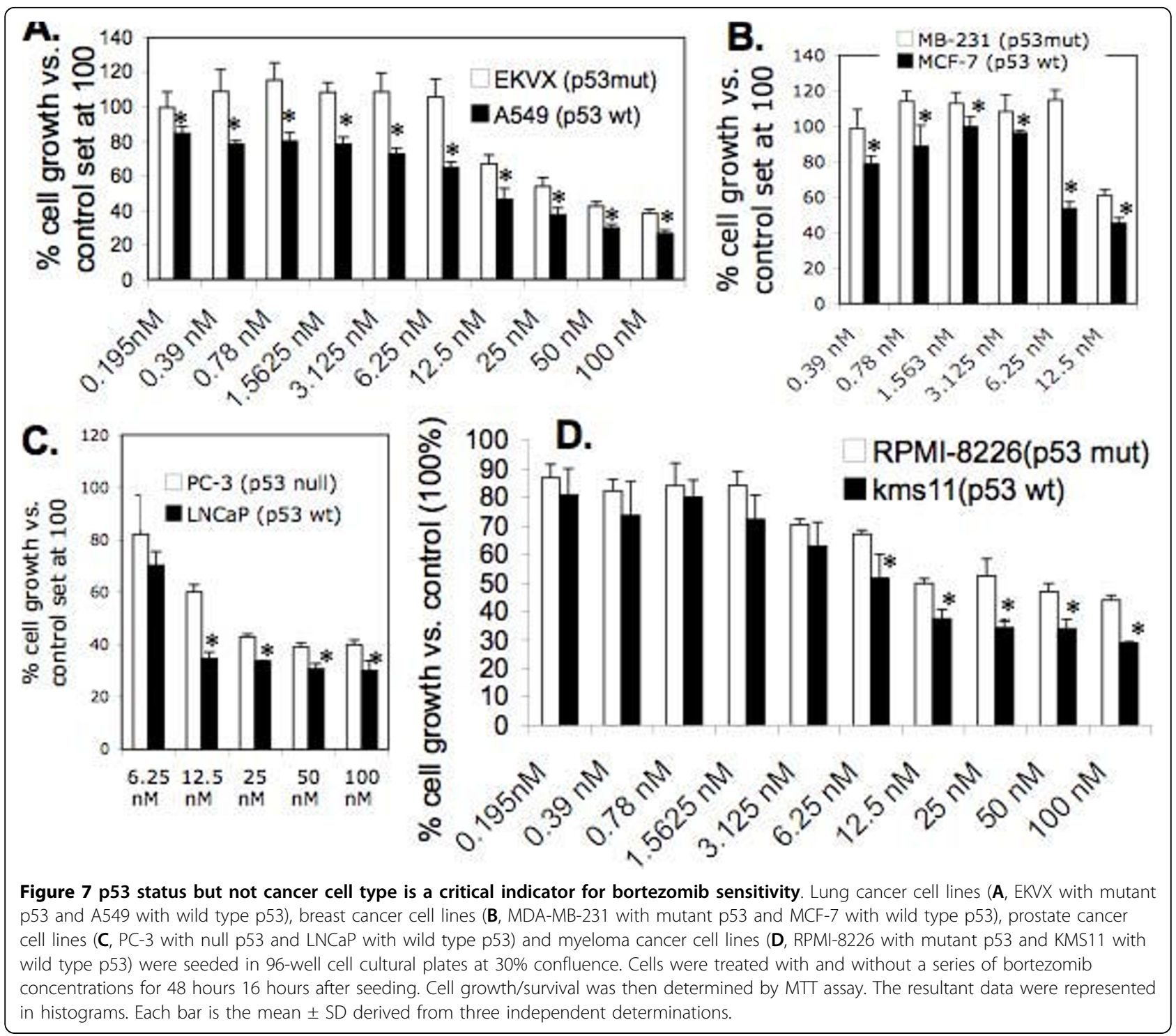

be further confirmed. As reviewed before, the survivin gene is a potential downstream target for p53 and NF$\kappa \mathrm{B}$ transcriptional regulation [26]. Alternatively, the previous finding that bortezomib stabilizes active form of p53 in human LNCaP-Pro5 prostate cancer cells may provide another explanation [40]. Nevertheless, while survivin expression is inhibited by wild type p53 [27-29], survivin and NF- $\kappa \mathrm{B}$ appear to be co-expressed in cancer such as in peripheral T-cell lymphoma [45], and inhibition of NF- $\kappa$ B activity using NF- $\kappa$ B-specific inhibitors decreased survivin expression [46]. Consistent with these observations, bortezomib resistance requires NF$\kappa \mathrm{B}$ activity in mantle cell lymphoma [47]. Therefore, the potential connection of these factors provide an interesting underlying mechanism, which is likely similar to the mechanism we recently discovered for the p53 and ER $\alpha$ on the survivin gene control in the breast cancer [30].
Finally, the p53 status in RPMI-8226 and Kms11 is not fully consistent in literature. Our literature search indicates that RPMI-8226 has mutant p53 [48], while Kms11 has wild type p53[49]. However, some publication indicated that $\mathrm{Kms} 11$ is p53 null. This is likely due to the hypermethylation of the p53 gene to make p53 expression extremely low [50]. Consistently, our results (Li and Chanan-Khan, unpublished observation) indicated that the expression of p53 in Kms11 was barely detected. Consistent with this, we found that the expression of survivin in Kms11 is comparable with its level in RPMI-8226 (Fig. 3C).

\section{Conclusion}

In conclusion, based on the finding in this study, survivin appears to play a role in bortezomib resistance. The p53 status-associated survivin expression is an important 
parameter for predicting bortezomib sensitivity, which is largely independent of cancer cell types. Therefore, the finding in this paper should be useful for not only prediction of bortezomib sensitivity, but may also be useful as an essential criterion for bortezomib combination with other anticancer compounds for treatment of cancer patients.

\section{Abbreviations}

bortezomib: PS-341 OR velcade ${ }^{\oplus}$; IAP: inhibitor of apoptosis; MTT: tetrazolium salt, 3-[4,5-dimethylthiazol-2-yl]-2,5,-diphenyltetrazolium bromide; NSCLC: non-small cell lung cancer; siRNA: small interference RNA.

\section{Acknowledgements}

This work was supported in part by NIH R01 Grants (CA109481, CA133241), a research grant (BCTR63806) from the Susan G. Komen for the Cure Foundation and a research grant from Charlotte Geyer Foundation to $\mathrm{FL}$, and by the NCl Cancer Center Support Grant to the Roswell Park Cancer Institute (CA016056). ACK is a Scholar of the Leukemia and lymphoma Society.

\section{Author details}

'Departments of Pharmacology Therapeutics, Roswell Park Cancer Institute, Buffalo, New York 14263, USA. 'Department of Medicine, Roswell Park Cancer Institute, Buffalo, New York 14263, USA. ${ }^{3}$ The Multiple Myeloma Research Group, Roswell Park Cancer Institute, Buffalo, New York 14263, USA. ${ }^{4}$ Department of Pediatrics, Emory University School of Medicine, Atlanta, GA 30322, USA.

\section{Authors' contributions}

$\mathrm{XL}$ carried out the experimental design, performed most of the experiments and organized data for manuscript. DC performed the rest of experiments and involved in results discussion and organization. AAC initiated bortezomib-related projects in our institute, helped experimental design and revised the manuscript. FL initiated the project, participated in experimental design and wrote the manuscript. All authors read and approved the final manuscript.

\section{Author information}

Diane Calinski was a student in the Roswell Park Summer College Student Program at the time for this work.

\section{Competing interests}

The authors declare that they have no competing interests.

Received: 6 July 2009

Accepted: 22 January 2010 Published: 22 January 2010

\section{References}

1. Fujita T, Doihara H, Washio K, Ino H, Murakami M, Naito M, Shimizu N: Antitumor effects and drug interactions of the proteasome inhibitor bortezomib (PS341) in gastric cancer cells. Anticancer Drugs 2007, 18:677-686.

2. Mackay H, Hedley D, Major P, Townsley C, Mackenzie M, Vincent M, Degendorfer $\mathrm{P}$, Tsao MS, Nicklee T, Birle D, et al: A phase II trial with pharmacodynamic endpoints of the proteasome inhibitor bortezomib in patients with metastatic colorectal cancer. Clin Cancer Res 2005, 11:5526-5533.

3. Kozuch PS, Rocha-Lima CM, Dragovich T, Hochster H, O'Neil BH, Atiq OT, Pipas JM, Ryan DP, Lenz HJ: Bortezomib with or without irinotecan in relapsed or refractory colorectal cancer: results from a randomized phase II study. J Clin Oncol 2008, 26:2320-2326.

4. Cardoso F, Durbecq V, Laes JF, Badran B, Lagneaux L, Bex F, Desmedt C, Willard-Gallo K, Ross JS, Burny A, et al: Bortezomib (PS-341, Velcade) increases the efficacy of trastuzumab (Herceptin) in HER-2-positive breast cancer cells in a synergistic manner. Mol Cancer Ther 2006, 5:3042-3051.
5. Codony-Servat J, Tapia MA, Bosch M, Oliva C, Domingo-Domenech J, Mellado B, Rolfe M, Ross JS, Gascon P, Rovira A, Albanell J: Differential cellular and molecular effects of bortezomib, a proteasome inhibitor, in human breast cancer cells. Mol Cancer Ther 2006, 5:665-675.

6. Yang $\mathrm{CH}$, Gonzalez-Angulo AM, Reuben JM, Booser DJ, Pusztai L, Krishnamurthy S, Esseltine D, Stec J, Broglio KR, Islam R, et al: Bortezomib (VELCADE) in metastatic breast cancer: pharmacodynamics, biological effects, and prediction of clinical benefits. Ann Oncol 2006, 17:813-817.

7. Engel RH, Brown JA, Von Roenn JH, O'Regan RM, Bergan R, Badve S, Rademaker A, Gradishar WJ: A phase II study of single agent bortezomib in patients with metastatic breast cancer: a single institution experience. Cancer Invest 2007, 25:733-737.

8. Awada A, Albanell J, Canney PA, Dirix LY, Gil T, Cardoso F, Gascon P, Piccart MJ, Baselga J: Bortezomib/docetaxel combination therapy in patients with anthracycline-pretreated advanced/metastatic breast cancer: a phase I/II dose-escalation study. Br J Cancer 2008, 98:1500-1507.

9. Schmid P, Kuhnhardt D, Kiewe P, Lehenbauer-Dehm S, Schippinger W Greil R, Lange W, Preiss J, Niederle N, Brossart P, et al: A phase I/II study of bortezomib and capecitabine in patients with metastatic breast cancer previously treated with taxanes and/or anthracyclines. Ann Oncol 2008, 19:871-876.

10. Papandreou CN, Logothetis CJ: Bortezomib as a potential treatment for prostate cancer. Cancer Res 2004, 64:5036-5043.

11. Price N, Dreicer R: Phase I/II trial of bortezomib plus docetaxel in patients with advanced androgen-independent prostate cancer. Clin Prostate Cancer 2004, 3:141-143

12. Papandreou CN, Daliani DD, Nix D, Yang $H$, Madden $T$, Wang $X$, Pien CS, Millikan RE, Tu SM, Pagliaro L, et al: Phase I trial of the proteasome inhibitor bortezomib in patients with advanced solid tumors with observations in androgen-independent prostate cancer. J Clin Oncol 2004, 22:2108-2121.

13. Morris MJ, Kelly WK, Slovin S, Ryan C, Eicher C, Heller G, Scher HI: A phase II trial of bortezomib and prednisone for castration resistant metastatic prostate cancer. J Urol 2007, 178:2378-2383.

14. Dreicer R, Petrylak D, Agus D, Webb I, Roth B: Phase I/II study of bortezomib plus docetaxel in patients with advanced androgenindependent prostate cancer. Clin Cancer Res 2007, 13:1208-1215.

15. Reddy KG: Activity of bortezomib in advanced non-small-cell lung cancer. Clin Lung Cancer 2004, 6:141-142.

16. Fanucchi MP, Fossella FV, Belt $R$, Natale $R$, Fidias $P$, Carbone DP Govindan R, Raez LE, Robert F, Ribeiro M, et al: Randomized phase II study of bortezomib alone and bortezomib in combination with docetaxel in previously treated advanced non-small-cell lung cancer. J Clin Oncol 2006, 24:5025-5033.

17. Lilenbaum R, Wang X, Gu L, Kirshner J, Lerro K, Vokes E: Randomized phase II trial of docetaxel plus cetuximab or docetaxel plus bortezomib in patients with advanced non-small-cell lung cancer and a performance status of 2: CALGB 30402. J Clin Oncol 2009, 27:4487-4491.

18. Li T, Ho L, Piperdi B, Elrafei T, Camacho FJ, Rigas JR, Perez-Soler R, Gucalp R: Phase II study of the proteasome inhibitor bortezomib (PS-341, Velcade $((\mathrm{R})))$ in chemotherapy-naive patients with advanced stage non-small cell lung cancer (NSCLC). Lung Cancer 2009.

19. Li F, Ambrosini G, Chu EY, Plescia J, Tognin S, Marchisio PC, Altieri DC: Control of apoptosis and mitotic spindle checkpoint by survivin. Nature 1998, 396:580-584

20. Altieri DC: Survivin in apoptosis control and cell cycle regulation in cancer. Prog Cell Cycle Res 2003, 5:447-452.

21. Li F: Survivin Study: What is the next wave?. J Cell Physiol 2003, 197:8-29.

22. Li F, Ling X: Survivin Study: An update of "What is the next wave?". J Cell Physiol 2006, 208:476-486.

23. Pennati M, Folini M, Zaffaroni N: Targeting survivin in cancer therapy. Expert Opin Ther Targets 2008, 12:463-476.

24. Altieri DC: The case for survivin as a regulator of microtubule dynamics and cell-death decisions. Curr Opin Cell Biol 2006, 18:609-615.

25. Wheatley SP, McNeish IA: Survivin: a protein with dual roles in mitosis and apoptosis. Int Rev Cytol 2005, 247:35-88.

26. Zhang M, Yang J, Li F: Transcriptional and post-transcriptional controls of survivin in cancer cells: novel approaches for cancer treatment. J Exp Clin Cancer Res 2006, 25:391-402.

27. Mirza A, McGuirk M, Hockenberry TN, Wu Q, Ashar H, Black S, Wen SF, Wang L, Kirschmeier P, Bishop WR, et al: Human survivin is negatively 
regulated by wild-type p53 and participates in p53-dependent apoptotic pathway. Oncogene 2002, 21:2613-2622.

28. Hoffman WH, Biade S, Zilfou JT, Chen J, Murphy M: Transcriptional repression of the anti-apoptotic survivin gene by wild type p53. J Biol Chem 2002, 277:3247-3257.

29. Zhou M, Gu L, Li F, Zhu Y, Woods WG, Findley HW: DNA Damage Induces a Novel p53-Survivin Signaling Pathway Regulating Cell Cycle and Apoptosis in Acute Lymphoblastic Leukemia Cells. J Pharmacol Exp Ther 2002, 303:124-131

30. Sayeed A, Konduri SD, Liu W, Bansal S, Li F, Das GM: Estrogen receptor alpha inhibits p53-mediated transcriptional repression: implications for the regulation of apoptosis. Cancer Res 2007, 67:7746-7755.

31. Vaziri SA, Hill J, Chikamori K, Grabowski DR, Takigawa N, Chawla-Sarkar M, Rybicki LR, Gudkov AV, Mekhail T, Bukowski RM, et al: Sensitization of DNA damage-induced apoptosis by the proteasome inhibitor PS-341 is p53 dependent and involves target proteins 14-3-3sigma and survivin. $\mathrm{Mol}$ Cancer Ther 2005, 4:1880-1890.

32. Gordon GJ, Mani M, Maulik G, Mukhopadhyay L, Yeap BY, Kindler HL, Salgia R, Sugarbaker DJ, Bueno R: Preclinical studies of the proteasome inhibitor bortezomib in malignant pleural mesothelioma. Cancer Chemother Pharmacol 2007, 61(4):549-58.

33. Liu $X$, Yue $P$, Chen $S$, Hu L, Lonial $S$, Khuri FR, Sun SY: The proteasome inhibitor PS-341 (bortezomib) up-regulates DR5 expression leading to induction of apoptosis and enhancement of TRAIL-induced apoptosis despite up-regulation of c-FLIP and survivin expression in human NSCLC cells. Cancer Res 2007, 67:4981-4988.

34. Jung CS, Zhou Z, Khuri FR, Sun SY: Assessment of Apoptosis-Inducing Effects of Docetaxel Combined with the Proteasome Inhibitor PS-341 in Human Lung Cancer Cells. Cancer Biol Ther 2007, 6(5):749-54.

35. Ling $X$, Li F: Silencing of antiapoptotic survivin gene by multiple approaches of RNA interference technology. BioTechniques 2004, 36:450-454, 456-460.

36. Ling $X$, Cheng Q, Black JD, Li F: Forced Expression of Survivin-2B Abrogates Mitotic Cells and Induces Mitochondria-dependent Apoptosis by Blockade of Tubulin Polymerization and Modulation of Bcl-2, Bax, and Survivin. J Biol Chem 2007, 282:27204-27214.

37. Ling X, He X, Apontes P, Cao F, Azrak RG, Li F: Enhancing effectiveness of the MDR-sensitive compound T138067 using advanced treatment with negative modulators of the drug-resistant protein survivin. Am J Trans/ Res 2009, 1:393-405.

38. Laubach JP, Mitsiades CS, Roccaro AM, Ghobrial IM, Anderson KC, Richardson PG: Clinical challenges associated with bortezomib therapy in multiple myeloma and Waldenstroms Macroglobulinemia. Leuk Lymphoma 2009, 50:694-702.

39. Curran MP, McKeage K: Bortezomib: a review of its use in patients with multiple myeloma. Drugs 2009, 69:859-888.

40. Williams SA, McConkey DJ: The proteasome inhibitor bortezomib stabilizes a novel active form of p53 in human LNCaP-Pro5 prostate cancer cells. Cancer Res 2003, 63:7338-7344.

41. Li F, Cheng Q, Ling X, Stablewski A, Tang L, Foster BA, Johnson CS, Rustum YM, Porter CW: Generation of a novel transgenic mouse model for bioluminescent monitoring of survivin gene activity in vivo at various pathophysiological processes: Survivin expression overlaps with stem cell markers. Am J Pathol 2010.

42. Li F: Every single cell clones from cancer cell lines growing tumors in vivo may not invalidate the cancer stem cell concept. Mol Cells 2009, 27:491-492.

43. Ling $X$, Bernacki RJ, Brattain MG, Li F: Induction of survivin expression by taxol (paclitaxel) is an early event which is independent on taxolmediated G2/M arrest. J Biol Chem 2004, 279:15196-15203.

44. Jatoi A, Dakhil SR, Foster NR, Ma C, Rowland KM Jr, Moore DF Jr, Jaslowski AJ, Thomas SP, Hauge MD, Flynn PJ, et al: Bortezomib, paclitaxel, and carboplatin as a first-line regimen for patients with metastatic esophageal, gastric, and gastroesophageal cancer: phase II results from the North Central Cancer Treatment Group (N044B). J Thorac Oncol 2008, 3:516-520.

45. Chang H, Gao Y, Zhang JY, Shi F, Chen YZ: [Expression of survivin and NFkappaB in peripheral T-cell lymphoma and its significance.]. Zhongguo Shi Yan Xue Ye Xue Za Zhi 2008, 16:1079-1081.

46. Sato A, Oya M, Ito K, Mizuno R, Horiguchi Y, Umezawa K, Hayakawa M, Murai M: Survivin associates with cell proliferation in renal cancer cells: regulation of survivin expression by insulin-like growth factor-1, interferon-gamma and a novel NF-kappaB inhibitor. Int J Oncol 2006, 28:841-846.

47. Yang DT, Young KH, Kahl BS, Markovina S, Miyamoto S: Prevalence of bortezomib-resistant constitutive NF-kappaB activity in mantle cell lymphoma. Mol Cancer 2008, 7:40.

48. Liu Q, Hilsenbeck S, Gazitt Y: Arsenic trioxide-induced apoptosis in myeloma cells: p53-dependent G1 or G2/M cell cycle arrest, activation of caspase-8 or caspase-9, and synergy with APO2/TRAIL. Blood 2003, 101:4078-4087.

49. Ooi MG, Hayden PJ, Kotoula V, McMillin DW, Charalambous E, Daskalaki E, Raje NS, Munshi NC, Chauhan D, Hideshima T, et al: Interactions of the $\mathrm{Hdm} 2 / \mathrm{p} 53$ and proteasome pathways may enhance the antitumor activity of bortezomib. Clin Cancer Res 2009, 15:7153-7160.

50. Hurt EM, Thomas SB, Peng B, Farrar WL: Reversal of $p 53$ epigenetic silencing in multiple myeloma permits apoptosis by a p53 activator. Cancer Biol Ther 2006, 5:1154-1160.

doi:10.1186/1756-9966-29-8

Cite this article as: Ling et al: Cancer cell sensitivity to bortezomib is associated with survivin expression and p53 status but not cancer cell types. Journal of Experimental \& Clinical Cancer Research 2010 29:8.

\section{Submit your next manuscript to BioMed Central and take full advantage of:}

- Convenient online submission

- Thorough peer review

- No space constraints or color figure charges

- Immediate publication on acceptance

- Inclusion in PubMed, CAS, Scopus and Google Scholar

- Research which is freely available for redistribution
C Biomed Central 